\title{
Glucose tolerance and serum concentrations of hormones and metabolites in goats (Capra hircus) fed diets supplemented with inorganic and organic chromium salts
}

\author{
S. Haldar ${ }^{1 \dagger}$, S. Samanta ${ }^{1}$, R. Banarjee ${ }^{2}$, B. Sharma ${ }^{1}$ and T. K. Ghosh ${ }^{1}$ \\ ${ }^{1}$ Department of Animal Nutrition, and; ${ }^{2}$ Department of Animal Products Technology and Marketing, Faculty of Veterinary and Animal Sciences, West Bengal \\ University of Animal and Fishery Sciences, 37 Kshudiram Bose Sarani, Kolkata 700037, India
}

(Received 16 June 2006; Accepted 13 November 2006)

\begin{abstract}
Adult goats (no. = 18) were supplemented with chromium $(\mathrm{Cr}, 0.5 \mathrm{mg} / \mathrm{kg}$ concentrate) for 120 days as $\mathrm{Cr}$ chloride and $\mathrm{Cr}$ yeast complex and their responses in terms of glucose tolerance and serum profiles of metabolites and hormones were measured. The goats were fed $200 \mathrm{~g} /$ day of the concentrate and reared under a semi-intensive regimen. Cr supplementation significantly reduced serum glucose $(\mathrm{P}=0.049)$ and cholesterol $(\mathrm{P}=0.0001)$ levels compared with the same in the control group (calculated as $\%$ change between days 0 and 120). Serum cortisol on day 120 was lower in goats fed $\mathrm{Cr}$ chloride than in the control group $(\mathrm{P}<0.05)$. Overall, the mean cortisol level was lower $(\mathrm{P}=0.001)$ in the goats receiving added dietary $\mathrm{Cr}$. An intravenous glucose tolerance test (IVGTT) was performed on the goats on day 75. The clearance rate ( $\mathrm{k}$ ) of glucose between 5 and 60 min of glucose infusion was significantly higher $(\mathrm{P}=0.004)$ in the goats supplemented with $\mathrm{Cr}$ yeast compared with those on the control or the $\mathrm{Cr}$ chloride supplemented diets. The kinetic parameters as well as the $\mathrm{k}$ and $T_{1 / 2}$ responses for serum insulin during the IVGTT were not affected. The ratio between the insulin $k$ to glucose $k$ increased $(\mathrm{P}=0.011)$ in the goats fed added dietary $\mathrm{Cr}$ as $\mathrm{Cr}$ chloride compared with the control and the $\mathrm{Cr}$ yeast groups. Post-prandial serum levels of glucose (diet effect $\mathrm{P}=0.038$ ) and cholesterol (diet effect $\mathrm{P}=0.033$ ) was lower in both the $\mathrm{Cr}$ supplemented groups than the control. Serum glucose during an epinephrine challenge test tended to remain elevated $(\mathrm{P}=0.076) 2 \mathrm{~h}$ after epinephrine infusion in the $\mathrm{Cr}$ yeast group indicating a delayed return of serum glucose to the basal level. However, serum insulin and cortisol remained unaffected. Several changes in selected blood metabolites and hormone measurements were observed when $\mathrm{Cr}$ was added as a dietary supplement in the diet of the goats. Contrary to the generally accepted view, supplemental Cr may influence the metabolism of ruminants even in a nonstressed management regime.
\end{abstract}

Keywords: chromium, glucose tolerance, goats, growth, metabolites

\section{Introduction}

Chromium ( $\mathrm{Cr}$ ) is an active component of the glucose tolerance factor and is important in carbohydrate, protein and fat metabolism, presumably by potentiating the action of insulin (Anderson, 1987; Mertz, 1993). Dietary recommendation for $\mathrm{Cr}$ is not listed for most livestock species including goats. Nevertheless, supplementation of $\mathrm{Cr}$ in livestock diets may improve animal metabolism and enhance production performance and the quality of animal products (Spears, 1999). Stress and diseases induce $\mathrm{Cr}$ deficiency by increasing glucose metabolism and causing release of corticosteroids. The result is mobilisation of tissue $\mathrm{Cr}$ and its irreversible loss through urine (Borel et al., 1984;

\footnotetext{
${ }^{\dagger}$ E-mail: rajhaldar2002@yahoo.com
}

Anderson, 1988) and an exacerbation of a marginal $\mathrm{Cr}$ deficiency (Sahin and Sahin, 2002) caused by insufficient $\mathrm{Cr}$ intake through dietary sources (Spears, 1999). Dietary $\mathrm{Cr}$ supplementation may be useful in alleviating such stress-induced losses of $\mathrm{Cr}$. However, choice of the source of supplemental $\mathrm{Cr}$ seems to be a crucial question and the organic $\mathrm{Cr}$ compounds like $\mathrm{Cr}$ picolinate or $\mathrm{Cr}$ in an organically complexed form like $\mathrm{Cr}$ yeast may have greater absorbability from the gut (Underwood and Suttle, 1999). It is uncertain if supplemental $\mathrm{Cr}$ would yield any appreciable beneficial effects in adult ruminants not exposed to any stressful condition. The present investigation was conducted using adult castrated male goats as a ruminant prototype reared under a semi-intensive management system with minimum possible stress per se. The objectives were 
to ascertain (i) if $\mathrm{Cr}$ supplementation influences circulatory cortisol and insulin in adult goats, and (ii) whether $\mathrm{Cr}$ yeast complex yields better results than $\mathrm{Cr}$ chloride, an inorganic reference source of $\mathrm{Cr}$, with respect to the aforementioned parameters and glucose tolerance.

\section{Material and methods}

\section{Feeding and management of experimental animals}

The experimental protocol used in this study was approved by the Institutional Animal Ethics Committee. The investigation employed adult castrated male black Bengal goats (Capra hircus) as the animal model (no. =18). The goats (average age 13 months, mean body weight $=14.3 \pm$ $0.75 \mathrm{~kg}$ ) were obtained from the flock maintained at the experimental farm of the University. The goats were treated for internal and external parasites $\left(0.2 \mathrm{mg}\right.$ Ivomec ${ }^{\circledR}$, administered parenterally) and vaccinated against peste des petits ruminants (the freeze-dried vaccine was supplied by the Indian Veterinary Research Institute, Mukteswar, India). Rectal temperatures were checked and any exceeding $40^{\circ} \mathrm{C}$ were treated with paracetamol and re-examined after 2 days. The animals were weighed again and distributed randomly into 3 treatment groups (no. $=6$ per treatment group) in such way that the variation between the treatment groups with regards to body weight was minimal $(P=0.99)$ at the start of the experiment (day 0$)$. The goats were reared under a semi-intensive farming system and accordingly, they were allowed to graze daily on a natural pasture of Cynodon dactylon from $0900 \mathrm{~h}$ to $1600 \mathrm{~h}$ and were placed in individual pens measuring $1.3 \times 2 \mathrm{~m}$ in an adjoining animal house for the remainder of the day. The pens were separated with plastic painted metal rails. The goats were tied in the morning and were offered individually $200 \mathrm{~g}$ of a concentrate mixture (Table 1) at $0700 \mathrm{~h}$. Refusals were negligible and hence were not collected for sampling. To minimise mineral contamination from inevitable sources plastic pans were used for offering feed and drinking water and de-mineralised water was supplied to the animals throughout the experiment. The trial lasted 120 days.

\section{Chromium supplementation of the experimental goats}

$\mathrm{Cr}$ was supplemented to the experimental goats through the concentrate diet either as chromic chloride hexahydrate $\left(\mathrm{CrCl}_{3}, 6 \mathrm{H}_{2} \mathrm{O}\right.$, molecular weight 266.45 , minimum assay 97\%, Hi-Media Laboratories, Mumbai, India) or in the form of $\mathrm{Cr}$ yeast complex (Chromesac ${ }^{\circledR}$, containing $400 \mathrm{mg} \mathrm{Cr}$ per $\mathrm{kg}$, supplied by the Zeus Biotech, Mysore India). The concentrate diet contained $0.5 \mathrm{mg}$ added $\mathrm{Cr}$ per $\mathrm{kg}$ (as-fed basis) from either of these sources. The experimental groups were, therefore, control (receiving no $\mathrm{Cr}$ supplementation), $\mathrm{Cr}$ chloride (containing $0.5 \mathrm{mg}$ added $\mathrm{Cr}$ per $\mathrm{kg}$ as $\mathrm{Cr}$ chloride) and $\mathrm{Cr}$ yeast (containing $0.5 \mathrm{mg}$ added $\mathrm{Cr}$ per $\mathrm{kg}$ as (hromesac $\left.{ }^{(B)}\right)$. Therefore, the goats consumed $0.1 \mathrm{mg} /$ day added $\mathrm{Cr}$ when consuming $200 \mathrm{~g} /$ day of
Table 1 Ingredients and chemical composition ( $\mathrm{g} / \mathrm{kg}$ dry matter unless stated otherwise) of the unsupplemented concentrate diet and pasture grass (Cynodon dactylon) fed to the experimental goats

\begin{tabular}{lcc}
\hline \hline Ingredients & Concentrate diet & Pasture grass \\
\hline Ground maize & 300 & \\
Ground nut cake & 140 & \\
Mustard oil cake & 50 & \\
Wheat bran & 350 & \\
Chick pea & 150 & \\
Mineral and vitamin pre-mix ${ }^{\dagger}$ & 10 & \\
Chemical composition & & \\
$\quad$ Dry matter (DM) & 882 & 808.5 \\
Organic matter (as fed) & 951 & 901.3 \\
Crude protein & 157.5 & 841.7 \\
$\quad$ Neutral-detergent fibre & 520 & 351.6 \\
$\quad$ Acid-detergent fibre & 210 & \\
Trace elements (mg/kg DM) & & 12.9 \\
$\quad$ Chromium & 0.76 & 196.5 \\
Copper & 17.4 & 75.6 \\
Iron & 113.9 & 36.9 \\
Manganese & 58.4 & \\
Zinc & 90.8 & \\
\hline \hline
\end{tabular}

${ }^{+}$Vitamin pre-mix provided the following per $100 \mathrm{~kg}$ of diet: vitamin A $(82500 \mathrm{IU}), B_{2}(50 \mathrm{mg}), D_{3}(12000 \mathrm{IU}), \mathrm{K}(10 \mathrm{mg}), 10 \mathrm{~g}$; vitamin $B$ complex $\left(B_{1}, B_{6}\right.$ and $B_{12}$, pantothenate and niacin) and vitamin $E, 20 \mathrm{~g}$. Mineral premix provided per $100 \mathrm{~kg}$ of diet: $\mathrm{NaCl}, 400 \mathrm{~g} ; \mathrm{NaHCO}_{3}, 100 \mathrm{~g} ; \mathrm{CuSO}_{4} 5 \mathrm{H}_{2} \mathrm{O}$, $6 \mathrm{~g} ; \mathrm{CoCl}_{2} 6 \mathrm{H}_{2} \mathrm{O}, 0.44 \mathrm{~g} ; \mathrm{ZnSO}_{4} 7 \mathrm{H}_{2} \mathrm{O}, 32 \mathrm{~g} ; \mathrm{FeSO}_{4} 7 \mathrm{H}_{2} \mathrm{O}, 21 \mathrm{~g} ; \mathrm{MnSO}_{4} \mathrm{H}_{2} \mathrm{O}, 33 \mathrm{~g}$; mixed in a dibasic calcium phosphate base $(400 \mathrm{~g})$.

concentrate. For fortification of the concentrate mixture with $\mathrm{Cr}$ chloride $128.1 \mathrm{mg}$ of $\mathrm{CrCl}_{3}, 6 \mathrm{H}_{2} \mathrm{O}$ was mixed thoroughly with $50 \mathrm{~g}$ of ground maize in a small capacity mixer which was subsequently mixed with $50 \mathrm{~kg}$ of the concentrate diet in a mechanical blender. To fortify the concentrate diet with $\mathrm{Cr}$ yeast, $62.5 \mathrm{~g}$ of Chromesac ${ }^{\circledR}$ was mixed thoroughly with $50 \mathrm{~kg}$ of the concentrate mixture to arrive at the desired concentration of $0.5 \mathrm{mg} / \mathrm{kg}$. The mean concentration of $\mathrm{Cr}$ in the unsupplemented concentrate diet was $0.76 \mathrm{mg} / \mathrm{kg}$ dry matter (DM) while that in the pasture grass was $0.93 \mathrm{mg} / \mathrm{kg}$ DM (Table 1).

\section{Performance study and sample collection}

Individual body weights were recorded at weekly intervals. Average daily gain (ADG) in body weight was calculated by subtracting the initial body weight from that on day 120. The samples of the unsupplemented concentrate diet were collected from each of the lots prepared while those of the pasture grass were collected at monthly intervals. These samples were dried at $80^{\circ} \mathrm{C}$ for $16 \mathrm{~h}$ in a forced air oven for estimation of DM, organic matter (OM) and crude protein (CP) contents (methods 942.05 and 984.13 of Association of Official Analytical Chemists (1995)) and neutral- and acid-detergent fibres (sulphate and amylase method of Van Soest et al. (1991)).

Blood samples (approx. $10 \mathrm{ml}$ ) were collected in sterilised glass tubes on day 0 and then on days 60, 90 and 120 of $\mathrm{Cr}$ supplementation from all the experimental animals at $0700 \mathrm{~h}$ after an overnight fast. Immediately after 
collection the tubes were placed in ice for $60 \mathrm{~min}$ to clot the blood, then centrifuged at 3000 r.p.m. for $15 \mathrm{~min}$. Glucose was estimated in serum within $2 \mathrm{~h}$ of serum separation and the remaining serum was transferred to polystyrene tubes, capped and stored $\left(-20^{\circ} \mathrm{C}\right)$ for later analyses of cholesterol, triacylglycerol, total protein and cortisol.

An intravenous glucose tolerance test (IVGTT) was performed on day 60 of $\mathrm{Cr}$ supplementation following the method standardised by Kaneko et al. (1997) and approved by the Institutional Animal Ethics Committee. The test was done on two consecutive days with three goats from each treatment group being tested on the 1st day and the remaining three on the other. The goats were fitted with sterile indwelling jugular catheters the day prior to the IVGTT. A 14-gauge thin wall needle was introduced into the jugular vein and a $30-\mathrm{cm}$ piece of 18-gauge thin wall Teflon tubing was introduced through the needle into the jugular vein. The needle was removed and the catheter was sutured to the skin. Catheter patency was maintained by a single flushing with heparin $(100 \mathrm{IU} / \mathrm{ml})$ in normal saline. After an overnight fast the pre-challenge blood samples ( $0 \mathrm{~min}$ ) were collected following which an intravenous bolus dose of glucose $(0.5 \mathrm{~g} / \mathrm{kg}$ body weight as $50 \%$ sterile solution) was administered at ambient temperature within a period of $30 \mathrm{~s}$ and this was immediately followed by a $10 \mathrm{ml}$ normal saline flush. Blood samples were collected 5, 15, 30, 45 and 60 min after glucose infusion in sterile glass vials which were placed in ice and serum was separated for glucose and insulin assay. The clearance rate $(k)$ for serum glucose was calculated between $5\left(t_{1}\right)$ and $60\left(t_{2}\right) \mathrm{min}$ and that of insulin was calculated between 0 $\left(t_{1}\right)$ and $45\left(t_{2}\right)$ min post infusion respectively in accordance to the standardised procedure outlined by Kaneko et al. (1997) using the following equation:

$$
k=100 \times\left[\left(I_{n}-I_{n}\right) /\left(t_{2}-t_{1}\right)\right]=\% \text { permin }
$$

in which $k$ (percentage per min) is the fractional turn over rate (or clearance rate) of serum glucose or insulin as calculated from the natural $\log \left(\mathrm{I}_{n}\right)$ of their circulating concentrations between $t_{1}$ and $t_{2}$. The serum half-life $\left(T_{1 / 2}\right)$ was calculated as follows:

$$
T_{1 / 2}=(0.693 / k) \times 100 \mathrm{~min}
$$

where $T_{1 / 2}$ is the half-life (min) of serum glucose or insulin and $k$ is the calculated fractional turn-over rate determined during $t_{1}$ and $t_{2}$.

A feeding challenge test was performed on day 75 employing all the goats of an experimental group. The prefeeding blood samples were collected at $0700 \mathrm{~h}$ after an overnight fast following the methodology described above. The goats were fed and bled again $2 \mathrm{~h}$ after feeding. The serum samples obtained were analysed for glucose, cholesterol, triacylglycerol and total protein. The change $(\%)$ in the concentration of the serum metabolites over the basal value at $2 \mathrm{~h}$ post prandial was determined as well.
An epinephrine challenge test (Kaneko et al., 1997) was performed on all the goats on day 110 of $\mathrm{Cr}$ supplementation. A fasting (pre challenge) blood sample was collected at $0700 \mathrm{~h}(0 \mathrm{~h})$ on the day of the test following the procedure described above which was immediately followed by an intramuscular administration of epinephrine hydrochloride (1000 international units). Subsequent samples of blood were collected after 30,60 and $120 \mathrm{~min}$ of epinephrine administration. The serum was separated and analysed for glucose, triacylglycerol, cortisol and insulin.

\section{Analyses of samples}

The concentration of $\mathrm{Cr}$ in the unsupplemented concentrate diet and pasture grass was estimated according to the methodology suggested by Perkin Elmer Inc. (Wellesley, MA, USA) with some modifications. Oven dried (at $80^{\circ} \mathrm{C}$ for $16 \mathrm{~h}$ ) samples were ground using a 1-mm sieve and $5 \mathrm{~g}$ subsamples were de-carbonised in glazed ceramic crucibles at $180^{\circ} \mathrm{C}$. These samples were then ignited in a muffle furnace at $400^{\circ} \mathrm{C}$ for $4 \mathrm{~h}$. The ash was treated with concentrated nitric acid under mild heat to oxidise the trivalent $\mathrm{Cr}$ to the hexavalent $\left(\mathrm{Cr}^{6+}\right)$ form, which could be detected more accurately. After complete digestion, the acid extracted samples were cooled at room temperature and filtered through ash-less Whatman filter paper (no.1). The crucibles were washed several times with triply distilled water and the final volume was made up to $10 \mathrm{ml}$. Cr was then estimated in an atomic absorption spectrophotometer (Perkin Elmer A Analyst 100). A 2\% solution of ammonium chloride was added in the standard and the samples to reduce interference caused by iron present in the samples. $\mathrm{Cr}$ in serum, on the other hand, was detected by aspirating the undiluted samples directly into the atomic absorption spectrophotometer.

Concentration of glucose, total protein, cholesterol and triacylglycerol was estimated photometrically in an automatic blood analyser (Microlab 200, E-Merck, Germany) using specific analytical kits (in vitro diagnostic kits manufactured by Erba Diagnostics, Manheim, Germany). An enzyme immuno-assay (Ranskan Sprint ELISA plate reader, Ranbaxy Diagnostics, New Delhi, India) was employed using commercial kits for estimation of insulin (Monobind Inc., Costa Mesa, USA) and cortisol (Equipar Diagnostica, Saronno $\mathrm{Va}$, Italy). The sensitivity of the respective assays was determined by measuring the concentration of serially diluted known standards and averaged $0.16 \mu \mathrm{U}$ and $0.17 \mathrm{ng}$ for insulin and cortisol respectively. The sample size in each assay was $200 \mu \mathrm{l}$. The intra-assay and interassay coefficients of variations were 5 and $9 \%$ and, 8 and $13 \%$ respectively for insulin and cortisol.

\section{Statistical analyses}

All the data were analyzed in the general linear model (GLM) of the Statistical Packages for the Social Sciences (1999) and the results were expressed in terms of mean and pooled standard error of mean. The data related to 
body weight and ADG and those obtained during the feeding challenge, IVGTT and the epinephrine challenge test were repeated measures within animals and hence repeated measure analysis of GLM was employed for analysis of these data. A single animal was considered as an experimental unit and the time interval for each of the measurements (body weight, serum metabolite and hormone concentrations during the feeding challenge, epinephrine challenge test and the kinetic parameters of glucose and insulin during the IVGTT) were considered as the within subject variables for assessing time effects. The diets (control, $\mathrm{Cr}$ chloride and $\mathrm{Cr}$ yeast) were considered as the between subject factors and diet effects were assessed. A diet $\times$ time interaction was added in the model. The data related to serum half-life and clearance rates of glucose and insulin were analysed using multivariate analysis of variance to assess the effects of dietary sources of $\mathrm{Cr}$ supplementation. Multiple comparisons of means under each dietary treatment group was done employing Tukey's test. A probability of $P<0.05$ was considered to be statistically significant and that of $P<0.10$ was described as a trend.

\section{Results}

\section{Body weight and live-weight gain}

The initial body weight of the goats was similar across the treatment groups $(P=0.99)$. The goats gained body weight during the experiment $(P<0.001)$ but neither the $A D G$ nor the final body weight was affected by dietary treatments (Table 2).

\section{Metabolites and hormones in blood}

Serum concentration of total protein, glucose and triacylglycerol measured on day 0 and that of cortisol and insulin measured on day 60 was similar $(P>0.1)$ across the treatment groups (Table 3). However, the initial (day 0) serum

Table 2 Body weight and average daily live-weight gain (ADG) in goats (no. $=6$ per treatment groups) fed diets supplemented with inorganic or organic trivalent chromium $\left(\mathrm{Cr}^{3+}\right)^{+}$

\begin{tabular}{lcccc}
\hline \hline & \multicolumn{3}{c}{ Dietary treatments $^{\ddagger}$} & \\
\cline { 2 - 4 } Measurements & Control & Cr-chloride & Cr-yeast & s.e. \\
\hline Body weight (kg) & & & & \\
$\quad$ Day 0 & 14.3 & 14.3 & 14.2 & 0.75 \\
Day 120 & 17.3 & 17.1 & 16.8 & 0.92 \\
Live-weight change (kg) & 3.01 & 2.73 & 2.52 & 0.33 \\
ADG (days 0-120) & 28.7 & 25.9 & 24.0 & 3.13 \\
\hline \hline
\end{tabular}

${ }^{\dagger}$ Supplementation lasted for 120 days. The goats were fed with a concentrate diet $(200 \mathrm{~g}$ per animal per day) and grazed on a natural pasture (Cynodon dactylon).

${ }^{\ddagger}$ Chromium was supplemented through the concentrate diet containing $0.5 \mathrm{mg}$ elemental $\mathrm{Cr}^{3+}$ per $\mathrm{kg}$ either from chromic chloride hexahydrate ( $\mathrm{Cr}$ chloride) or chromium yeast complex ( $\mathrm{Cr}$ yeast). The control group of goats was fed with an unsupplemented concentrate diet. There were no significant treatment effects $(P>0.1)$. cholesterol was lower in the control group of the goats compared with groups given supplemental $\mathrm{Cr}(P<0.05)$. On the other hand, serum cholesterol on day 120 was lower in the goats fed added dietary $\mathrm{Cr}$ from $\mathrm{Cr}$ chloride and $\mathrm{Cr}$ yeast relative to the control group of goats $(P<0.05)$ and the overall mean serum cholesterol concentration also tended to be lower in the $\mathrm{Cr}$ supplemented goats (overall diet effect $P=0.075$ ).

Added dietary $\mathrm{Cr}$ failed to affect the serum concentration of total protein, glucose and triacylglycerol. The change (\%) in serum concentration of the metabolites and hormones between the initial and the final measurements was calculated and a significant difference between the dietary treatment groups was detected with regards to the change in serum glucose (diet effect $P=0.049$ ) and cholesterol (diet effect $P=0.0001$ ) concentration. Serum glucose in the control group of goats increased while that in both the $\mathrm{Cr}$ supplemented groups decreased (day effect $P=0.002$, day $\times$ diet $P=0.059$ ). Serum cholesterol changed little in the control group of the goats between days 0 and 120. However, in the goats receiving added dietary $\mathrm{Cr}$ from $\mathrm{Cr}$ chloride and $\mathrm{Cr}$ yeast serum cholesterol declined by $44.4 \%$ and $43.2 \%$ respectively (day effect $P=0.0001$, day $\times$ diet $P=0.0001$ ). However, unlike serum cholesterol, serum triacylglycerol increased on day 120 (day effect $P=0.0001)$ relative to the initial concentration on day 0 irrespective of dietary treatments (diet effect $P>0.1$, day $\times$ diet $P=0.22$ ).

Dietary treatment had no significant effect $(P>0.1)$ on serum insulin concentration (Table 3 ). Serum cortisol on day 120 was lower in the goats receiving added dietary $\mathrm{Cr}$, especially in those supplemented with $\mathrm{Cr}$ chloride, compared with the control group of goats $(P=0.008)$. The change in serum cortisol with time was significant (time effect $P=0.002$ ). Compared with the concentration on day 60 , serum cortisol increased in the control group and declined in the $\mathrm{Cr}$ chloride group while in the $\mathrm{Cr}$ yeast group of goats it changed little during the said time period (day $\times$ diet interaction $P=0.003$ ).

\section{Intravenous glucose tolerance test}

Serum glucose and insulin concentrations and the $k$ and $T_{1 / 2}$ responses following the intravenous glucose infusion are presented in Table 4 . The basal $(0 \mathrm{~min})$ concentrations of serum glucose and insulin were similar across treatment groups $(P>0.1)$. Both of these serum parameters changed with time $(P=0.0001)$ and there was a significant time $\times$ diet effect $(P=0.044$ for glucose and $P=0.0001$ for insulin).

Serum glucose increased sharply and then gradually decreased following glucose infusion. The peak serum glucose concentration, which was reached at 5 min post infusion, was lower in the goats receiving added dietary $\mathrm{Cr}$ from $\mathrm{Cr}$ chloride $(P=0.039)$. At $60 \mathrm{~min}$ post infusion serum glucose was lower in the goats fed added dietary $\mathrm{Cr}$ through $\mathrm{Cr}$ yeast $(P=0.049)$, indicating a quicker return to basal concentration than in the other two groups. 
Table 3 Metabolites and hormones in pre-feeding serum samples of goats supplemented with inorganic (Cr chloride) or organic (Cr yeast) trivalent chromium $\left(\mathrm{Cr}^{3+}\right)$ for 120 days (no. $=6$ per treatment group)

\begin{tabular}{|c|c|c|c|c|c|c|c|c|}
\hline \multirow[b]{2}{*}{ Response variables } & & \multicolumn{3}{|c|}{ Dietary treatments ${ }^{\dagger}$} & \multirow[b]{2}{*}{ s.e. } & \multicolumn{3}{|c|}{ Significance } \\
\hline & & Control & Cr chloride & $\mathrm{Cr}$ yeast & & Diet & Day & Day $\times$ diet \\
\hline \multirow[t]{4}{*}{ Total protein $(\mathrm{g} / \mathrm{l})$} & Day 0 & 68.1 & 65.3 & 68.0 & 1.22 & & & \\
\hline & Day 60 & 73.6 & 73.4 & 74.5 & 3.57 & & & \\
\hline & Day 120 & 67.6 & 67.9 & 67.9 & 1.82 & & & \\
\hline & Mean & 69.7 & 68.8 & 69.2 & 1.38 & & & \\
\hline Change (\% day 0 ) & & 0.7 & 4.5 & 0.26 & 2.39 & & & \\
\hline \multirow{4}{*}{ Glucose (mmol/l) } & Day 0 & 2.59 & 2.94 & 3.15 & 0.137 & & & \\
\hline & Day 60 & $2.46^{\mathrm{a}}$ & $3.06^{\mathrm{b}}$ & $2.93^{b}$ & 0.091 & & & \\
\hline & Day 120 & 2.41 & 1.98 & 2.34 & 0.136 & & & \\
\hline & Mean & 2.62 & 2.77 & 2.73 & 0.069 & & $* *$ & $\dagger$ \\
\hline Change (\% day 0$)$ & & 6.63 & -21.1 & -21.9 & 4.83 & * & & \\
\hline \multirow[t]{4}{*}{ Cholesterol (mmol/l) } & Day 0 & $2.18^{a}$ & $2.50^{b}$ & $2.39^{b}$ & 0.036 & * & & \\
\hline & Day 60 & 2.33 & 2.33 & 2.26 & 0.066 & & & \\
\hline & Day 120 & $2.19^{b}$ & $1.38^{\mathrm{a}}$ & $1.35^{\mathrm{a}}$ & 0.076 & $* * *$ & & \\
\hline & Mean & 2.23 & 2.04 & 1.99 & 0.04 & ${ }^{\dagger}$ & $* * *$ & $* * *$ \\
\hline Change (\% day 0 ) & & $0.45^{\mathrm{a}}$ & $-44.4^{b}$ & $-43.2^{b}$ & 3.65 & $* * *$ & & \\
\hline \multirow[t]{4}{*}{ Tri-acylglycerol (mmol/l) } & Day 0 & 0.483 & 0.441 & 0.461 & 0.025 & & & \\
\hline & Day 60 & 0.835 & 0.736 & 0.759 & 0.027 & & & \\
\hline & Day 120 & 0.649 & 0.532 & 0.527 & 0.027 & & & \\
\hline & Mean & 0.639 & 0.571 & 0.550 & 0.018 & & $* * *$ & \\
\hline Change (\% day 0 ) & & 40.3 & 23.5 & 14.8 & 8.28 & & & \\
\hline \multirow[t]{4}{*}{ Cortisol (ng/ml) } & Day 60 & 35.2 & 34.8 & 35.5 & 2.17 & & & \\
\hline & Day 90 & 49.3 & 38.4 & 38.3 & 2.20 & & & \\
\hline & Day 120 & $44.6^{\mathrm{b}}$ & $25.2^{\mathrm{a}}$ & $35.8^{\mathrm{ab}}$ & 1.87 & $* *$ & & \\
\hline & Mean & $47.0^{\mathrm{b}}$ & $32.8^{a}$ & $36.5^{\mathrm{a}}$ & 1.87 & $* * *$ & ** & ** \\
\hline Change ( $\%$ day 60 ) & & 26.7 & -27.6 & 0.84 & 17.8 & & & \\
\hline \multirow[t]{3}{*}{ Insulin $(\mu \mathrm{U} / \mathrm{ml})$} & Day 60 & 19.2 & 19.1 & 18.3 & 0.92 & & & \\
\hline & Day 120 & 21.7 & 26.1 & 19.5 & 1.70 & & & \\
\hline & Mean & 20.5 & 22.7 & 18.8 & 0.82 & & & \\
\hline Change (\%day 60) & & 18.2 & 45.7 & 8.0 & 11.98 & & & \\
\hline
\end{tabular}

${ }^{a, b}$ Means bearing dissimilar superscripts within a row vary significantly.

${ }^{\dagger}$ Approaching significance $(P<0.1)$.

Serum insulin also increased following the intravenous glucose infusion reaching a peak at 45 min post infusion. Dietary $\mathrm{Cr}$ supplementation failed to elicit any effect on serum insulin concentration during the IVGTT $(P>0.1)$. Interestingly, unlike the $\mathrm{Cr}$ chloride and $\mathrm{Cr}$ yeast dietary groups, in the control group of the goats serum insulin at 15 min post infusion was lower than the baseline $(0 \mathrm{~min})$ concentration (resulting a significant time $\times$ diet interaction $P=0.0001)$. However, the change in serum insulin $(\%$ basal value) between 0 and 60 min post infusion was similar across the dietary treatments $(P>0.1)$.

Both the $k$ and the $T_{1 / 2}$ responses for insulin during the IVGTT were not affected by dietary $\mathrm{Cr}$ supplementation $(P>0.1)$. However, the glucose $k$ between 5 and $60 \mathrm{~min}$ post infusion was higher $(P<0.05)$ in goats receiving added dietary $\mathrm{Cr}$ from $\mathrm{Cr}$ yeast and this was accompanied by a lower glucose $T_{1 / 2}$ in this dietary group. Added dietary $\mathrm{Cr}$ had little effect $(P>0.1)$ on the molar ratio of insulin and glucose calculated during the IVGTT. However, the ratio between the insulin $k$ and glucose $k$ was higher in the $\mathrm{Cr}$ chloride supplemented group $(P<0.05)$ (Tables 5 and 6$)$.
Post-prandial changes in serum metabolite concentrations Dietary $\mathrm{Cr}$ supplementation improved post-prandial utilisation of glucose $(P=0.038)$ and that of cholesterol $(P=0.033)$ with lower serum levels of these metabolites being detected in the $\mathrm{Cr}$ chloride and $\mathrm{Cr}$ yeast dietary groups than in the control group. Dietary treatment had no effect $(P>0.1)$ on the post-prandial changes in serum levels of triacylglycerol and total protein.

\section{Epinephrine challenge test}

Serum glucose and triacylglycerol during the epinephrine challenge test were not affected by dietary $\mathrm{Cr}$ supplementation $(P>0.1)$. Serum glucose increased $30 \mathrm{~min}$ after epinephrine infusion regardless of dietary treatments confirming that the animals were responding to the epinephrine challenge. In the $\mathrm{Cr}$ yeast supplemented goats serum glucose at $2 \mathrm{~h}$ post infusion tended to by higher than in control and $\mathrm{Cr}$ chloride groups $(P<0.1)$.

Regardless of dietary treatments serum triacylglycerol started declining after $30 \mathrm{~min}$ of epinephrine infusion to reach a level lower than that detected at $0 \mathrm{~min}$. The trend 
Haldar, Samanta, Banarjee, Sharma and Ghosh

Table 4 Effect of supplemental chromium $\left(\mathrm{Cr}^{3+}\right)$ on intravenous glucose tolerance test measurements for serum glucose and serum insulin in adult goats (no. $=6$ per treatment group)

\begin{tabular}{|c|c|c|c|c|c|c|}
\hline \multirow[b]{2}{*}{ Response variables $^{\dagger}$} & & \multicolumn{3}{|c|}{ Dietary treatments } & \multirow[b]{2}{*}{ s.e. } & \multirow{2}{*}{$\begin{array}{l}\text { Significance } \\
\text { of diet effect }\end{array}$} \\
\hline & & Control & Cr chloride & $\mathrm{Cr}$ yeast & & \\
\hline \multirow[t]{5}{*}{ Glucose (mmol/l) } & $0 \min$ & 2.66 & 3.01 & 2.69 & 0.09 & \\
\hline & $5 \mathrm{~min}$ & $10.79^{\mathrm{b}}$ & $9.68^{\mathrm{a}}$ & $11.64^{\mathrm{b}}$ & 0.27 & * \\
\hline & $15 \min$ & 8.45 & 9.31 & 9.77 & 0.47 & \\
\hline & $45 \mathrm{~min}$ & 5.19 & 6.29 & 6.57 & 0.36 & \\
\hline & $60 \min$ & $4.49^{b}$ & $4.89^{\mathrm{b}}$ & $3.39^{\mathrm{a}}$ & 0.23 & * \\
\hline \multicolumn{2}{|c|}{ Change $(0-5 \mathrm{~min}) \%$} & $308^{\mathrm{ab}}$ & $223^{\mathrm{a}}$ & $338^{\mathrm{b}}$ & 4.17 & ** \\
\hline \multicolumn{2}{|c|}{ Change $(0-60 \mathrm{~min}) \%$} & $69.1^{\mathrm{b}}$ & $62.1^{\mathrm{b}}$ & $26.3^{\mathrm{a}}$ & 7.63 & * \\
\hline \multicolumn{2}{|c|}{ Glucose $k \%$ per min $(5-60 \mathrm{~min})$} & $1.63^{\mathrm{a}}$ & $1.25^{\mathrm{a}}$ & $2.27^{\mathrm{b}}$ & 0.096 & ** \\
\hline \multicolumn{2}{|c|}{ Glucose $T_{1 / 2} \min (5-60 \mathrm{~min})$} & $45.0^{\mathrm{ab}}$ & $56.2^{\mathrm{b}}$ & $31.3^{\mathrm{a}}$ & 2.23 & ** \\
\hline \multirow[t]{4}{*}{ Insulin $(\mu \mathrm{U} / \mathrm{ml})$} & $0 \mathrm{~min}$ & 19.2 & 19.1 & 18.3 & 0.77 & \\
\hline & $15 \min$ & 18.4 & 21.5 & 13.9 & 1.00 & \\
\hline & $45 \mathrm{~min}$ & 24.0 & 28.0 & 23.9 & 0.51 & \\
\hline & $60 \min$ & 21.8 & 21.5 & 20.3 & 0.14 & \\
\hline \multirow{2}{*}{\multicolumn{2}{|c|}{$\begin{array}{l}\text { Change }(0-15 \mathrm{~min}) \% \\
\text { Change }(0-60 \mathrm{~min}) \%\end{array}$}} & -7.2 & 12.6 & 6.4 & 3.94 & \\
\hline & & 17.2 & 14.9 & 11.7 & 4.62 & \\
\hline \multicolumn{2}{|c|}{ Insulin $k \%$ per min $(0-45 \mathrm{~min})$} & 1.58 & 2.59 & 2.24 & 0.248 & \\
\hline \multirow{2}{*}{\multicolumn{2}{|c|}{$\begin{array}{l}\text { Insulin } T_{1 / 2} \text { minute }(0-45 \mathrm{~min}) \\
\text { Insulin: glucose (molar ratio) }\end{array}$}} & 79.3 & 29.1 & 34.8 & 11.59 & \\
\hline & & & & & & \\
\hline & $0 \min$ & 52.8 & 45.6 & 50.4 & 3.26 & \\
\hline & $15 \min$ & 16.3 & 17.1 & 14.2 & 0.93 & \\
\hline & $45 \mathrm{~min}$ & 16.3 & 17.1 & 14.2 & 0.93 & \\
\hline & $60 \min$ & 38.3 & 31.9 & 44.9 & 3.27 & \\
\hline Insulin $k$ : glucose $k$ & & $0.96^{\mathrm{a}}$ & $2.1^{\mathrm{b}}$ & $1.0^{\mathrm{a}}$ & 0.145 & * \\
\hline
\end{tabular}

${ }^{a, b}$ Means bearing dissimilar superscripts within a row differ significantly.

${ }^{\dagger}$ Response variables were measured during an IVGTT performed on day 60 of supplemental $\mathrm{Cr}$ feeding. For glucose: significant time effect $P=0.0001$, time $\times$ diet effect $P=0.044$. For insulin: significant time effect $P=0.0001$, time $\times$ diet effect $P=0.0001$.

Table 5 Serum metabolite concentrations at 0 and $2 \mathrm{~h}$ post prandial in adult goats (no. $=6$ per treatment group) supplemented with inorganic (Cr chloride) or organic (Cr yeast) trivalent chromium $(\mathrm{Cr})^{\dagger}$

\begin{tabular}{|c|c|c|c|c|c|c|c|}
\hline \multirow[b]{2}{*}{ Measurements $^{\ddagger}$} & \multicolumn{3}{|c|}{ Dietary treatments } & \multirow[b]{2}{*}{ s.e. } & \multicolumn{3}{|c|}{ Significance } \\
\hline & Control & Cr chloride & $\mathrm{Cr}$ yeast & & Diet & Time & Diet $\times$ time \\
\hline \multicolumn{8}{|l|}{ Glucose (mmol/l) } \\
\hline $\mathrm{Oh}$ & 3.06 & 3.11 & 2.58 & 0.109 & $\S$ & $* * *$ & \\
\hline $2 \mathrm{~h}$ & $4.42^{\mathrm{b}}$ & $3.60^{\mathrm{a}}$ & $3.53^{a}$ & 0.125 & * & & \\
\hline$\%$ change over $0 \mathrm{~h}$ value & 27.2 & 13.5 & 25.9 & 6.84 & & & \\
\hline \multicolumn{8}{|l|}{ Cholesterol (mmol/l) } \\
\hline $0 \mathrm{~h}$ & $2.09^{b}$ & $1.28^{\mathrm{a}}$ & $1.00^{\mathrm{a}}$ & 0.085 & $* * *$ & $* * *$ & \\
\hline $2 \mathrm{~h}$ & $2.7^{\mathrm{b}}$ & $1.93^{\mathrm{ab}}$ & $1.76^{\mathrm{a}}$ & 0.135 & * & & \\
\hline$\%$ change over $0 \mathrm{~h}$ value & 30.9 & 76.9 & 76.7 & 17.15 & & & \\
\hline \multicolumn{8}{|l|}{ Triglyceride $(\mathrm{mmol} / \mathrm{l})^{3}$} \\
\hline $\mathrm{Oh}$ & $0.57^{\mathrm{ab}}$ & $0.59^{b}$ & $0.44^{\mathrm{a}}$ & 0.022 & * & & \\
\hline $2 \mathrm{~h}$ & 0.63 & 0.53 & 0.54 & 0.026 & & & \\
\hline$\%$ change over $0 \mathrm{~h}$ value & 8.3 & -17.6 & 17.9 & 6.3 & $\S$ & & \\
\hline \multicolumn{8}{|l|}{ Protein $(g / l)$} \\
\hline $\mathrm{Oh}$ & 69.2 & 68.7 & 66.5 & 2.09 & & & $\S$ \\
\hline $2 \mathrm{~h}$ & 63.6 & 65.4 & 73.9 & 2.18 & & & \\
\hline$\%$ change over $0 \mathrm{~h}$ value & $-10.5^{\mathrm{a}}$ & $-3.4^{\mathrm{a}}$ & $11.6^{\mathrm{b}}$ & 3.34 & * & & \\
\hline
\end{tabular}

${ }^{\dagger}$ The test was performed after 75 days of $\mathrm{Cr}$ supplementation.

${ }^{\ddagger}$ For glucose: over all diet effect $P=0.032$. For cholesterol: over all diet effect $P=0.0001$. For triglyceride: over all diet effect $P=0.082$.

${ }^{\S}$ Approaching significance $(P<0.1)$. 
Table 6 Effects of feeding trivalent chromium $\left(\mathrm{Cr}^{3+}\right)$ on serum metabolite and hormone concentrations in adult goats during an epinephrine challenge test (no. $=6$ per treatment group) ${ }^{\dagger}$

\begin{tabular}{|c|c|c|c|c|c|}
\hline \multirow[b]{2}{*}{ Concentrations of ${ }^{\ddagger}$} & \multicolumn{3}{|c|}{ Dietary treatments } & \multirow[b]{2}{*}{ s.e. } & \multirow{2}{*}{$\begin{array}{l}\text { Significance } \\
\text { of diet effect }\end{array}$} \\
\hline & Control & Cr chloride & $\mathrm{Cr}$ yeast & & \\
\hline \multicolumn{6}{|c|}{ Serum glucose (mmol/l) } \\
\hline $0 \mathrm{~min}$ & 2.18 & 2.01 & 2.34 & 0.14 & \\
\hline $30 \mathrm{~min}$ & 3.48 & 3.99 & 4.75 & 0.378 & \\
\hline $60 \min$ & 7.23 & 6.62 & 7.76 & 1.05 & \\
\hline $120 \min$ & 3.06 & 3.38 & 5.09 & 0.35 & $\S$ \\
\hline \multicolumn{6}{|c|}{ Triglyceride (mmol/l) } \\
\hline $0 \min$ & 0.72 & 0.78 & 0.75 & 0.038 & \\
\hline $30 \mathrm{~min}$ & 0.77 & 0.81 & 0.82 & 0.039 & \\
\hline $60 \min$ & 0.58 & 0.62 & 0.69 & 0.048 & \\
\hline $120 \mathrm{~min}$ & 0.53 & 0.53 & 0.47 & 0.026 & \\
\hline \multicolumn{6}{|l|}{ Cortisol (ng/ml) } \\
\hline $0 \min$ & 44.6 & 25.2 & 35.5 & 1.87 & \\
\hline $30 \mathrm{~min}$ & 48.6 & 28.5 & 36.4 & 1.59 & \\
\hline $60 \min$ & 30.2 & 27.2 & 34.9 & 1.47 & \\
\hline $120 \mathrm{~min}$ & 21.0 & 20.6 & 16.6 & 1.72 & \\
\hline \multicolumn{6}{|l|}{ Insulin ( $\mu \mathrm{IU} / \mathrm{ml})$} \\
\hline $0 \min$ & 21.9 & 26.3 & 19.3 & 1.7 & \\
\hline $30 \mathrm{~min}$ & 17.1 & 16.7 & 18.1 & 0.49 & \\
\hline $60 \min$ & 18.0 & 17.6 & 16.8 & 0.62 & \\
\hline $120 \mathrm{~min}$ & 18.9 & 18.9 & 15.9 & 0.75 & \\
\hline
\end{tabular}

${ }^{\dagger}$ The test was performed on day 110 of $\mathrm{Cr}$ supplementation.

${ }^{\ddagger}$ For serum glucose: time effect $P=0.0001$, time - diet $P=0.43$. For triglyceride: time effect $P=0.0001$, time $-\operatorname{diet} P=0.829$. For cortisol: time effect $P=0.002$, time $-\operatorname{diet} P=0.182$. For insulin: time effect $P=0.004$, time diet $P=0.053$

${ }_{\S}^{\S}$ Approaching significance $(P<0.1)$.

with regards to changes in serum cortisol levels during the epinephrine challenge test was rather inconspicuous and not affected by dietary treatment $(P>0.1)$.

Serum insulin declined with time after epinephrine challenge and the extent of this decline tended to be more pronounced in the $\mathrm{Cr}$ chloride group of goats (time $\times$ diet interaction $P=0.059$ ).

\section{Discussion}

Potentiation of insulin action is presumed to be the mechanism that explains the action of $\mathrm{Cr}$. $\mathrm{Cr}$ is considered to be an integral part of the glucose tolerance factor, which facilitates the cellular binding and action of insulin (DePew et al., 1998). It has been reported that supplemental $\mathrm{Cr}$ feeding may improve body weight and feed efficiency in pigs (Page et al., 1993), broiler chickens (Ahmed et al., 2005), goats (Paul et al., 2005) and dairy heifers (Biswas et al., 2006). On the other hand $\mathrm{Cr}$ supplementation has been found to have no relationship with body weight and associated performance traits in ruminating feeder calves (Bunting et al., 1994; Kegley and Spears, 1995), steers (Besong et al., 2001), dairy cows (Hayirli et al., 2001) and sheep (Kitchalong et al., 1995; Sano et al., 2000). Achieving discernible effects of supplemental $\mathrm{Cr}$ on the production and metabolic indices of adult ruminants is still a debatable issue owing to the fact that functional ruminants derive little glucose from intestinal absorption, and the role of insulin in ruminants is perhaps less well defined than that in non-ruminants (Brockman, 1986). Evaluation of growth responses to $\mathrm{Cr}$ was not the main objective of this experiment, which used relatively mature goats. Conspicuous effects of supplemental $\mathrm{Cr}$ on growth of the animals were lacking in this experiment.

The cholesterol lowering effect of added dietary $\mathrm{Cr}$ observed in this study was consistent with our earlier work with pre-pubertal dairy heifers (Biswas et al., 2006). The hypocholesterolemic effect of supplemental $\mathrm{Cr}$ may be related to an augmented insulin action which might have increased lipogenesis and reduced lipolysis, the result being lowered circulatory lipid concentration (Mertz, 1993; Spears, 1999). Interestingly, neither the serum level of glucose nor that of insulin was affected significantly by $\mathrm{Cr}$ supplementation in the present study and the average molar ratio between insulin and glucose during the trial period, which was similar across the treatment groups $(P>0.1)$, did not indicate an improved insulin action per se. Nevertheless, when subjected to the intravenous glucose loading during the IVGTT, the Cr supplemented goats exhibited improvement in glucose utilisation which is consistent with an enhancement in insulin action. As occurs in human subjects (Mertz, 1993) these subtle changes in insulin action might have influenced lipid metabolism to elicit a hypocholesterolemic effect. Increment in serum insulin level due to $\mathrm{Cr}$ supplementation in goats has been reported earlier (Haldar et al., 2006). Besong et al. (1996) also reported increased serum insulin and decreased plasma non-esterified fatty acids (NEFA) concentrations in pre partum cows receiving $0.8 \mathrm{mg} \mathrm{Cr}$ picolinate per $\mathrm{kg} \mathrm{DM}$. The present findings, however, tallied partially with those of Hayirli et al. (2001) who reported that supplementation of $\mathrm{Cr}$ as $\mathrm{Cr}$ methionine in pre-partum cows caused an increased serum insulin concentration associated with decreased basal plasma NEFA without affecting plasma glucose and molar ratio of insulin to glucose. Contrarily, the same workers reported that in post-partum cows plasma glucose and NEFA concentrations were not altered due to $\mathrm{Cr}$ supplementation despite an improvement in action of insulin (revealed by a lower molar ratio of insulin to glucose in the supplemented cows vis-à-vis the control ones). Thus, from the results presented herein and the ones reported earlier, it seems that the response to added dietary $\mathrm{Cr}$ is more discernible for cholesterol metabolism than it is for carbohydrate metabolism.

Potentiation of insulin action due to $\mathrm{Cr}$ supplementation should have enhanced retention of protein at tissue level and consequently changes in circulatory blood protein levels are expected (Chang and Mowat, 1992; MoonsieShageer and Mowat, 1993). Cr has a known involvement in the utilisation of amino acids and synthesis of nuclear protein and RNA and might result in increased nitrogen (N) retention (Britton et al., 1968; Bunting et al., 1994). 
Chang and Mowat (1992) reported increased serum protein levels in growing steers fed with a high $\mathrm{Cr}$ yeast complex. In contrast no difference in the concentrations of total protein and other $\mathrm{N}$ metabolites were reported in heifers and steer calves (Bunting et al., 1994) and sheep (Kitchalong et al., 1995) which corroborated the present findings. Perhaps it would be inappropriate to correlate the concentration of the $\mathrm{N}$ metabolites in serum with the status of protein metabolism in the experimental goats since the former may lack adequate sensitivity required to predict subtle changes in protein metabolism that may arise as a result of $\mathrm{Cr}$ supplementation.

The role of supplemental $\mathrm{Cr}$ in reducing circulatory cortisol level in ruminants is well established (Chang and Mowat, 1992; Moonsie-Shageer and Mowat, 1993; Mowat et al., 1993; Haldar et al., 2006). Most of the findings depicting a reduction in the circulatory cortisol level due to $\mathrm{Cr}$ supplementation involved one or more stress factors like transportation or vaccination. The present investigation corroborated these earlier findings though in this case $\mathrm{Cr}$ yeast complex caused a reduction in cortisol concentration despite absence of any stress per se. Considering the generally known immuno-suppressive and anti-inflammatory role of cortisol (Borgs and Mallard, 1998), the reduction in circulatory cortisol concentration due to $\mathrm{Cr}$ supplementation might have implications in developing newer tools for performance enhancement of ruminant livestock.

The IVGTT is a practical and simple test to measure the efficiency of insulin mediated glucose utilisation in ruminants. In an earlier study with the same animal model Haldar et al. (2006) reported that the clearance rate $(k)$ of both glucose and insulin increased and their $T_{1 / 2}$ decreased due to $\mathrm{Cr}$ (as $\mathrm{Cr}$ chloride) supplementation. However, in the present investigation, the $k$ and $T_{1 / 2}$ of insulin remained unaffected though those of glucose improved indicating an enhancement in glucose tolerance (ability of a subject to maintain blood glucose level closer to the basal value after an oral or intravenous loading of glucose (Kaneko et al., 1997)). It may be argued that development of an age dependent insulin resistance (inability of a subject to show a normal insulin response after an oral or intravenous glucose loading) might have precluded a conspicuous treatment effect as it was reported by Kitchalong et al. (1995). Insulin resistance can be evaluated by insulin responsiveness, insulin sensitivity, or both (Kahn, 1978). Following glucose infusion the peak concentration of serum glucose reflects insulin responsiveness and the clearance rate of glucose from the serum indicates towards the insulin sensitivity (Kahn, 1978; Sano et al., 1991). As long as serum insulin concentrations are similar during the IVGTT, as they were during the present investigation, a higher glucose peak with a slower $k$ and a longer $T_{1 / 2}$ would be suggestive of glucose intolerance. So, in the present investigation significantly lower peak serum glucose following the intravenous infusion of glucose was one of the indications towards improved insulin responsiveness in the goats receiving added dietary $\mathrm{Cr}$ as $\mathrm{Cr}$ chloride.
Moreover, it was this particular dietary group in which the ratio between the insulin $k$ to glucose $k$ was significantly higher suggesting improved tissue sensitivity to insulin as well. However, the longer $T_{1 / 2}$ in the $\mathrm{Cr}$ chloride group of goats was rather unexpected and could not be explained. The shorter glucose $T_{1 / 2}$ in the $\mathrm{Cr}$ yeast group was due to the sharp decline in serum glucose level between $5 \mathrm{~min}$ (peak concentration) and $60 \mathrm{~min}(70.8 \%)$ in that group relative to the control (58.3\%) and the $\mathrm{Cr}$ chloride (49.5\%) groups. Consequently the clearance rate of glucose increased which was in agreement with the earlier findings in this regard (Kitchalong et al., 1995; Subiyatno et al., 1996; Hayirli et al., 2001). When summed up, the results of the IVGTT indicated that intake of as little as $0.1 \mathrm{mg}$ added dietary $\mathrm{Cr}$ may improve the insulin mediated glucose metabolism in goats which ought to augment the overall production criteria of this small ruminant species.

The 0 and $2 \mathrm{~h}$, post-prandial serum metabolite concentrations did not reveal any effect of $\mathrm{Cr}$ supplementation and this was in partial agreement with the earlier findings (Kitchalong et al., 1995; Gentry et al., 1999). The $2 \mathrm{~h}$ postprandial serum glucose indicated a better utilisation of glucose after feeding which corroborated the results obtained during the IVGTT. Serum cholesterol at 0 and $2 \mathrm{~h}$ post prandial and the basal triacylglycerol levels revealed significant effect of $\mathrm{Cr}$ on lipid metabolism as did earlier workers (Bunting et al., 1994; Kitchalong et al., 1995; DePew et al., 1996; Subyatno et al., 1996). Results from this study, therefore, support the suggestion that $\mathrm{Cr}$ supplementation has the potential to alter lipid metabolism (Riales and Albrink, 1981). The lower serum triacylglycerol at $0 \mathrm{~h}$, however, was contrary to several earlier works reporting little or no effect of supplemental $\mathrm{Cr}$ on serum triacylglycerol level (Page et al., 1993; DePew et al., 1996; Besong et al., 2001). No idea as regards to the effects of supplemental $\mathrm{Cr}$ on post-prandial utilisation of protein could be developed from the serum protein levels at 0 and $2 \mathrm{~h}$ post prandial.

The epinephrine challenge test was performed to ascertain if supplemental $\mathrm{Cr}$ could alleviate the stress induced on the animals by infusion of epinephrine. However, the metabolite and hormone concentrations in the serum of the goats during the epinephrine challenge test did not reveal any definite effect of $\mathrm{Cr}$ supplementation. Unlike the response obtained during the IVGTT serum glucose in the $\mathrm{Cr}$ yeast supplemented goats stayed more elevated than the basal value even after $2 \mathrm{~h}$ of epinephrine infusion which might be related to the lower level of insulin activity in that particular group. Though the goats in the $\mathrm{Cr}$ yeast group were able to maintain the glucose homeostasis despite such a lower basal level of insulin they perhaps became intolerant to the glucose flux produced by epinephrine which is a strong glycogenolytic catecholamine. The decline in serum insulin following the epinephrine challenge was rather difficult to explain and contradicted the earlier findings in this regard (Kitchalong et al., 1995; Gentry et al., 1999). However, in the present investigation epinephrine was introduced intra muscularly while most of 
the other workers employed the intravenous route. This variation in the route of epinephrine administration might have had blunted the responses during the present study.

During the present investigation the goats consumed as little as $0.1 \mathrm{mg}$ added dietary $\mathrm{Cr}$ per day while in our earlier investigation comparatively younger goats were supplemented with $0.5 \mathrm{mg}$ to $1.5 \mathrm{mg} \mathrm{Cr}$ per day (Haldar et al., 2006). In fact, the dose level of supplemental $\mathrm{Cr}$ employed in this study was lower than that used in earlier studies involving large ruminants $(0.2$ to $0.8 \mathrm{mg} / \mathrm{kg}$ diet DM). Therefore, it may be argued that the present inclusion level of $\mathrm{Cr}$ in diet might not be sufficient. However, the reduction in circulatory cortisol and cholesterol in conjunction with an improved glucose tolerance during the IVGTT indicated that intake of the added dietary $\mathrm{Cr}$ at the level employed in the present investigation may also significantly manoeuvre the metabolic criteria of adult goats.

\section{Conclusion}

The present investigation revealed changes in glucose tolerance and selected blood metabolites and hormone measurements when $\mathrm{Cr}$ was added as a supplement in the diet of goats. Contrary to the generally accepted hypothesis, supplemental $\mathrm{Cr}$ may influence the metabolism of animals even in a non-stressed management regime. However, the comparison between $\mathrm{Cr}$ chloride and $\mathrm{Cr}$ yeast as the source of supplemental $\mathrm{Cr}$ remained inconclusive.

\section{Acknowledgement}

The authors gratefully acknowledge the grant received from the Agricultural Produce Cess Fund of the Indian Council of Agricultural Research, New Delhi, India for conducting the investigation.

\section{References}

Ahmed N, Haldar S and Ghosh TK 2005. Growth performances, nutrient utilization and carcass traits in broiler chickens fed with a normal and a low energy diet supplemented with inorganic chromium (as chromic chloride hexahydrate) and a combination of inorganic chromium and ascorbic acid. Journal of Agricultural Science, Cambridge 143, 427-439.

Anderson RA 1987. Chromium. In Trace elements in human and animal nutrition (ed. W Mertz), pp. 225-244. Academic Press, New York.

Anderson RA 1988. Chromium. In Trace elements in foods (ed. KT Smith), pp. 231-247. Marcel Dekker Inc., New York.

Association of Official Analytical Chemists 1995. Official methods of analysis, 16th edition. Association of Official Analytical Chemists, Arlington, VA.

Besong S, Jackson JA, Trammell DS and Akay V 2001. Influence of supplemental chromium on concentrations of liver triacylglycerol, blood metabolites and rumen VFA profile in steers fed a moderately high fat diet. Journal of Dairy Science 84, 1679-1685.

Besong S, Jackson JA, Trammell DS and Amaral-Phillips D 1996. Effects of supplemental chromium picolinate on liver triacylglycerols, blood metabolites, milk yield and milk composition in early lactation cows. Journal of Dairy Science 79, (suppl.) 197 (abstr.).

Biswas P, Haldar S, Pakhira MC, Ghosh TK and Biswas C 2006. Efficiency of nutrient utilization and reproductive performance of pre-pubertal dairy heifers supplemented with inorganic and organic chromium compounds. Journal of the Science of Food and Agriculture 86, 804-815.
Borel JS, Majeres TC, Polansky M, Moser PB and Anderson RA 1984. Chromium intake and urinary chromium excretion of trauma patients. Biological Trace Element Research 6, 317-321.

Borgs P and Mallard BA 1998. Immune-endocrine interaction in agricultural species: chromium and its effect on health and performance. Domestic Animal Endocrinology 15, 431-438.

Britton RA, McLaren GA and Jett DA 1968. Influence of cane molasses on NPN utilization and fiber digestibility. Journal of Animal Science 27, 1510 (abstr.).

Brockman RP 1986. Pancreatic and adrenal hormone regulation of metabolism. In Control of digestion and metabolism in ruminants (ed. LP Milligan, WL Grovum and A Dobson), pp. 405-419. Prentice-Hall, Englewood Cliffs, NJ.

Bunting LD, Fernandez JM, Thompson DL Jr and Southern LL 1994. Influence of chromium picolinate on glucose usage and metabolic criteria in growing Holstein calves. Journal of Animal Science 72, 1591-1599.

Chang $X$ and Mowat DN 1992. Supplemental chromium for stressed and growing feeder calves. Journal of Animal Sciences 70, 559-565.

DePew CL, Bunting LD, Fernandez JM, Thompson DL Jr and Adkinson RW 1998. Performance and metabolic responses of young dairy calves fed diets supplemented with chromium tripicolinate. Journal of Dairy Science 81, 2916-2923.

DePew CL, Bunting LD, Fernandez JM, Thompson DL Jr and Gantt DT 1996. Chromium picolinate does not alter intake or lipid metabolism in lambs fed standard or high-fat diets. Journal of Dairy Science 79, (suppl.) 140 (abstr.).

Gentry LR, Fernandez JM, Ward TL, White TW, Southern LL, Bidner TD, Thompson JD. L, Horohov DW, Chapa AM and Sahlu T 1999. Dietary protein and chromium tripicolinate in Suffolk wether lambs: effects on production characteristics, metabolic and hormonal responses, and immune status. Journal of Animal Science 77, 1284-1294.

Haldar S, Ghosh TK, Pakhira MC and De K 2006. Effects of incremental dietary chromium $\left(\mathrm{Cr}^{3+}\right)$ on growth, hormone concentrations and glucose clearance in growing goats (Capra hircus). Journal of Agricultural Science, Cambridge $144,269-280$.

Hayirli A, Bremmer DR, Bertics SJ, Socha MT and Grummer RR 2001. Effect of chromium supplementation on production and metabolic parameters in periparturient dairy cows. Journal of Dairy Science 84, 1218-1230.

Kahn CR 1978. Insulin resistance, insulin sensitivity, and insulin responsiveness: a necessary distinction. Metabolism 27, 1893-1902.

Kaneko JJ, Harvey JW and Bruss ML 1997. Clinical biochemistry of domestic animal (ed. JJ Kaneko), pp. 890-894. Academic Press, New York.

Kegley EB and Spears JW 1995. Immune responses, glucose metabolism, and performance of stressed feeder calves fed inorganic and organic chromium. Journal of Animal Science 73, 2721-2726.

Kitchalong L, Fernandez JM, Bunting LD, Southern LL and Bidner TD 1995. Influence of chromium tripicolinate on glucose metabolism and nutrient partitioning in growing lambs. Journal of Animal Sciences 73, 2694-2705.

Mertz W 1993. Chromium in human nutrition: a review. Journal of Nutrition 123, 626-633.

Moonsie-Shageer S and Mowat DN 1993. Effect of level of supplemental chromium on performance, serum constituents, and immune status of stressed feeder calves. Journal of Animal Science 71, 232-238.

Mowat DN, Chang X and Yang WZ 1993. Chelated chromium for stressed feeder calves. Canadian Journal of Animal Sciences 73, 49-55.

Page TG, Southern LL, Ward TL and Thomson DL 1993. Effect of chromium picolinate on growth and serum and carcass traits of growing-finishing pigs. Journal of Animal Science 71, 656-662.

Paul TK, Haldar S and Ghosh TK 2005. Growth performance and nutrient utilization in black Bengal bucks (Capra hircus) supplemented with graded doses of chromium as chromium chloride hexahydrate. Journal of Veterinary Science 6, 33-40.

Riales R and Albrink MJ 1981. Effect of chromium chloride supplementation on glucose tolerance and serum lipids including high-density-lipoprotein of adult men. American Journal of Clinical Nutrition 34, 2670-2678.

Sahin K and Sahin N 2002. Effects of chromium picolinate and ascorbic acid dietary supplementation on nitrogen and mineral excretion of laying hens reared in a low ambient temperature $\left(7^{\circ} \mathrm{C}\right)$. Acta Veterinaria Brno 71 , 183-189. 


\section{Haldar, Samanta, Banarjee, Sharma and Ghosh}

Sano H, Konno S and Shiga A 2000. Chromium supplementation does not influence glucose metabolism or insulin action to cold exposure in mature sheep. Journal of Animal Science 78, 2950-2956.

Sano $H$, Nakai T, Kondo $T$ and Terashima $Y$ 1991. Insulin responsiveness to glucose and tissue responsiveness to insulin in lactating, pregnant, and non-pregnant, non-lactating, beef cows. Journal of Animal Science 69, 1122-1127.

Spears JW 1999. Reevaluation of the metabolic essentiality of the minerals review. Asian Australian Journal of Animal Science 12, 1002-1008.
Statistical Packages for the Social Sciences 1999. Version 10.0. SPSS, Chicago, IL. Subiyatno A, Mowat DN and Yang WZ 1996. Metabolite and hormonal responses to glucose or propionate infusion in periparturient dairy cows supplemented with chromium. Journal of Dairy Science 79, 1436-1445.

Underwood EJ and Suttle NF 1999. The mineral nutrition of livestock, 3rd edition. CABI Publishing, London.

Van Soest PJ, Robertson JB and Lewis BA 1991. Methods for dietary fiber, neutral detergent fiber and non-starch polysaccharides in relation to animal nutrition. Journal of Dairy Sciences 74, 3583-3597. 